\title{
Corporate governance in sustainability indexes: a Spanish case study
}

\author{
El gobierno corporativo en los índices de sostenibilidad: un \\ estudio de caso español
}

\author{
Andreu-Pinillos, A., Fernández-Fernández, J. L. \& Fernández-Mateo, J. ${ }^{1}$ \\ Recibido: 13-05-2020 - Aceptado: 15-08-2020 \\ https://doi.org/10.26441/RC19.2-2020-A1
}

\begin{abstract}
In recent years, corporate governance and corporate social responsibility have come closer in academic research, and especially on sustainability indexes. In fact, the most significant indexes handle the matter of corporate governance along with other environmental and social criteria. The purpose of this study is to find out if all the variables included in the corporate governance dimension on the above mentioned indicators are equally relevant and material for both corporate social responsability and corporate governance. To carry out the study, a sample of academics and professionals from Spanish universities and businesses sector was taken. We defend the plausible hypothesis that not all items included within corporate governance dimension on sustainability indexes are homogeneous and interchangeable and, therefore, equally relevant. As a result, the measurements provided by these indexes may not be truly representative.
\end{abstract}

Keywords: corporate sustainability; corporate governance; sustainability indexes; boards of directors; corporate social responsibility; business ethics.

RESUMEN: En los últimos años, el gobierno corporativo y la responsabilidad social de las empresas se han acercado en la investigación académica, y especialmente en los índices de sostenibilidad. De hecho, los índices más importantes tratan la cuestión del gobierno corporativo junto con otros criterios ambientales y sociales. El propósito de este estudio es descubrir si todas las variables incluidas en la dimensión gobierno corporativo de los índices mencionados son igualmente relevantes y materiales tanto para la responsabilidad social de las empresas como para el gobierno corporativo. Para llevar a cabo el estudio, se ha tomado una muestra de académicos y profesionales del ámbito universitario y empresarial español. Defendemos la hipótesis plausible de que no todos los elementos incluidos en la dimensión gobierno corporativo de los índices de sostenibilidad son homogéneos e intercambiables y, por lo tanto, igualmente relevantes. Como consecuencia, las mediciones que proporcionan estos índices pueden no ser verdaderamente representativas.

Palabras clave: sostenibilidad corporativa; gobierno corporativo; índices de sostenibilidad; consejos de administración; responsabilidad social corporativa; ética de los negocios.

\footnotetext{
${ }^{1}$ Alberto Andreu-Pinillos is a Ph. D. in Economy by the Pontifical University Comillas of Madrid and has a Master's Degree in Business Administration (MBA) at IE Business School. Current position: Executive Director of Master in Human Resources and Digitalisation at the School of Economics \& Business Administration of the University of Navarra. albertoandreu@unav.es, https://orcid.org/0000-0003-1312-0899

José-Luis Fernández-Fernández is a Ph. D. in Philosophy by the Pontifical University Comillas of Madrid and has a Master's Degree in Business Administration (MBA) at ICADE Business School. Current position: Full Professor \& Director of the Iberdrola Chair in Economic and Business Ethics at the Pontifical University Comillas of Madrid. jlfernandez@icade.comillas.edu, http://orcid.org/0000-0002-2344-7169

Joaquín Fernández-Mateo is a Ph. D. in Contemporary Challenges in the Information Society by the Complutense University of Madrid and has a Master's Degree in Political and Institutional Communication by Ortega y Gasset Foundation. Current position: Associate Professor at the Department of Education Sciences, Language, Arts and Culture at the Rey Juan Carlos University. joaquin.fernandez@urjc.es, https://orcid.org/0000-0002-9560-5197
} 


\section{Introduction}

Historically, Corporate Governance (hereinafter CG) and Corporate Social Responsibility (hereinafter CSR) have been studied as separate dimensions: 'much of the previous literature has researched and discussed CG and CSR independently, as being unrelated accountability models, whose guidelines, reporting standards, and oversight mechanisms have evolved separately' (Jamali et al., 2008: 444). However, there is literature on the integration of CSR into government systems (Blair, 1996; Bird, 2001; Aguilera et al., 2006; Elkington, 2006) and there are already many data that show that CG and CSR are two sides of the same coin: a bibliographical review has revealed that the two concepts have started to merge together (Ricart et al., 2005; Money \& Schepers, 2007; Jamali et al., 2008; Spitzeck, 2009; Kolk \& Pinkse, 2010; Harjoto \& Jo, 2011, Jo \& Harjoto, 2012; Chan et al., 2014, Rodriguez-Fernández, 2016; Andreu et al., 2018; Shu \& Chiang, 2020; Rubino \& Napoli, 2020). This situation represents an opportunity to open a new research and was the inception for the present study.

It has also been proven that there is a positive correlation between CG, CSR and economic performance (Fowler \& Hope, 2007; López et al., 2007; Huang, 2010; Harjoto \& Jo, 2011; Chan et al. 2014; Friede et al., 2015; Khan et al., 2016) and that the main Environment, Social and Governance (ESG) rating agencies - Bloomberg ESG Data Service; EIRIS; Vigeo, ROBECO-SAM; MSCI ESG Research; Sustainalytics Company ESG Reports and Thomson Reuters ESG Research Data - handle the question of CG along with other environmental and social criteria (Fowler and Hope, 2007; De la Cuesta et al., 2015; Avetisyan \& Hockerts, 2017).

According to studies by Fowler and Hope (2007), the CG issues on the Dow Jones Sustainability Index (DJSI) - one of the most relevant indexes for corporate sustainability - have a weight of $5.4 \%$ regarding the total index. This percentage would increase to $12 \%$ if topics are considered such as risk management (with a weight of 3.6\%) and codes of conduct/compliance/corruption and bribery (another 3\%) (See Table 1):

Table 1. DJSI weightings: corporate sustainability assessment criteria (Economic dimension 30,6\%)

\begin{tabular}{|l|c|}
\hline Codes of Conduct/Compliance/Corruption & 3.0 \\
\hline Corporate Governance & 5.4 \\
\hline Customer Relationship Management & 3.0 \\
\hline Financial Robustness & 3.6 \\
\hline Investor Relations & 2.4 \\
\hline Risk \& Crisis Management & 3.6 \\
\hline Scorecards/Measurement Systems & 4.2 \\
\hline Strategic Planning & 5.4 \\
\hline Industry Specific Criteria & Industry dependent \\
\hline
\end{tabular}

Prepared by authors following Fowler and Hope, 2007: 248

It has also been shown that there is a feeling of uncertainty and mistrust that separates us from the expectable requirement of objectivity — or materiality (Eccles et al, 2012; Eccles \& Youmans, 2016; Khan et al., 2016) - with regard to sustainability indexes, due to a series of shortcomings revealed via academic and professional research. For Fowler and Hope (2007: 251) 'to date, we are not aware of any serious academic research into the methodology behind the construction of sustainable indexes'. Several studies have been critical with the weights assigned to the variables that comprise the sustainability indexes (Adam and Shavit, 2008; Donker and Zahir, 2008; Escrig et 
al., 2010). Windolph (2011) has developed a systematic description of the challenges that corporate sustainability ratings face: lack of standardisation, lack of credibility of information, bias, tradeoffs, lack of transparency and lack of independence. Searcy \& Elkhawas (2012) underlined the challenges associated with the lack of standardisation in corporate sustainability reporting and performance measurement.

This gap is even greater for issues related to CG (De la Cuesta et al., 2015) due to many factors, among which we should point out the nonexistence of an ecosystem of organisations and institutions working in public scrutiny of CG issues and being unaware of relevant $C G$ indicators which should be part of the sustainability questionnaires (Andreu et al., 2018). The situation continues despite the outcries of large international fund managers, which consider this issue a priority (BlackRock, 2016).

In short, the presence of subjective matters has been proven in drafting the indexes of the ESG rating agencies that continue to be identified even now in the most recent studies, revealing, among other factors: inconsistencies between the measurements provided by the ESG rating agencies indexes, the existence of biases that appear due to the locations of the companies studied-European companies obtain higher scores - their capitalisation - the largest companies obtain better ratings - the sector to which they belong, or an insufficient measurement of risk (Doyle, 2018). All these problems lead to a lack of materiality (Eccles et al, 2012; Eccles \& Youmans, 2016; Khan et al., 2016) that is discovered due to the inconsistence and incoherence of the data provided. However, 'whether their measurements are accurate or not, ESG rating agencies undoubtedly influence the behavior of firms and investors. Addressing ESG issues has become a point of interest as a risk-management concern for investors, shareholders, and governments' (Avetisyan \& Hockerts, 2017).

Thus, studying the different relevancy of the variables related to corporate governance on sustainability indexes, it is essential to find out their greater or lesser interest and impact on corporate sustainability (Eccles et al., 2014). This is particularly important because after the financial crisis the investors appreciate corporate sustainability more than before the financial crisis (Rossouw, 2012; Baas et al., 2016), although the COVID-19 outbreak could change ESG priorities (BarreiroGen et al., 2020). Our research studies the relevance of questionnaire variables by measuring them on two factors: CSR and CG. This is the reason why we speculate, as a research hypothesis, that there are items that have more relevance and impact than other items for CG and CSR, a theory we will try to confirm here.

\section{Conceptual framework}

The definitions considered for conducting this research study are:

Corporate Social Responsibility (CSR). Academic literature has proposed a large number of definitions for the term 'corporate social responsibility' (Dahlsrud, 2008), but in general 'CSR can be defined as an instrument for applying the concept of corporate sustainability' (Kleine and Von Hauff, 2009). For Montiel (2008: 246):

Historically, social issues research has been grounded in CSR and environmental issues research in environmental management (EM). In recent years CS - which includes social and environmental issues - has entered the discourse, further blurring research boundaries. Although CS and CSR have evolved from different histories, they are pushing toward a common future. They both share the same vision, which intends to balance economic responsibilities with social and environmental ones.

Currently, the term CSR is usually associated with corporate sustainability (CS) (Van Marrewijk, 2003; Lo \& Sheu, 2007; Andreu et al., 2018; Montiel et al., 2020). For this reason, for the sake of simplicity, in this study the terms CSR and CS are used interchangeably and equivalently appearing 
in most cases as CSR. Indeed, the scope of the term sustainability, with a meaning oriented toward ecological sustainable development has expanded toward economic and social factors:

The core idea was defined most influentially by The World Commission on Environment and Development (i.e., The Brundtland Commission) as 'development which meets the needs of the present without compromising the ability of future generations to meet their own needs' (1987: 8). In its broadest sense, this normative abstraction has been widely accepted and endorsed by thousands of governmental, corporate, and other organizations worldwide (Gladwin et al., 1995: 876).

Corporate Governance (CG). CG refers to the entirety of legal, cultural and institutional rules and standards that determine what corporations can do that are listed on the stock market, who controls them, how this control is exercised and how the risks and benefits of the activities they do are assigned (Blair, 1996). For Shleifer and Vishny (1997, p. 737) CG 'deals with the ways in which suppliers of finance to corporations assure themselves of getting a return on their investment'. However, CSR has progressively penetrated the boards of directors and 'wider issues such as business ethics through entire value chains, human rights, bribery and corruption, and climate change are among the great issues of our time that increasingly cross-cut the rarified worlds of corporate boardrooms' (Elkington, 2006: 522). For Beltratti (2005: 384) 'corporate governance and corporate social responsibility are therefore complementary' and 'firms with a good corporate governance are also more respected and valuable. Therefore, a good corporate governance protects the stakeholders which contribute to the life of the firm' (2005: 385). For the OECD (2016) CG are practices that facilitate the creation of an atmosphere of confidence, transparency, and accountability necessary to favour long-term investments, financial stability and integrity in businesses.

The integration of CSR in the boards of directors guarantees the return of the investment and the lifetime of the company. Companies that adopt a comprehensive set of corporate policies relating to the environment, employees, community, products, and the environment outperform their counterparts over the long term, both in terms of stock market and accounting performance. High sustainability firms pay attention to externalities and are characterised by governance mechanisms that directly involve the board in sustainability issues, linking executive compensation to sustainability objectives (Eccles et al., 2014). A resposible corporate governance is key.

Sustainability Indexes: They are the tools that try to make the values of CSR/CS tangible. Sustainability indexes, like traditional stock market indexes, are indicators of the price trends shown by the most representative shares on a stock market. Nonetheless, in this case, the market is limited to socially responsible companies. Investors can exclude from their portfolios those companies that do not respect human rights and the environment, or that generate profits via ethically questionable activities (Sun et al., 2011). The measurements designed by rating agencies were successful due to initially consisting of an independent judgement of companies' reports and for giving credibility to the notion of socially responsible investment, namely, investing in companies that have integrated $\mathrm{CSR} / \mathrm{CS}$ criteria and that, therefore, have the ability to create long term value (De la Cuesta et al., 2015; López et al, 2007)

However, despite the growth of environmental, social, and governance (ESG) rating agencies, 'there is no standard methodology for the evaluation of firms. A major reason is the complexity of developing synthetic sustainability indexes. There are calls in the academic world for the establishment of a standard assessment methodology' (Escrig et al., 2014). Sustainability indexes are constantly changing, and it is not uncommon to find out new studies that suggest new questions for the questionnaires and changes in the scores assigned to each dimension (Fernández-Mateo \& Franco-Barrera, 2020). If there is a variation in the dimensions over the years (See Table 2), the weights of the items that compose it could also change: this require a critical review to assess their materiality. 
In this research, the following inexes have been used to evaluate the materiality of the questions in the sustainability questionnaires in their governance dimension: EIRIS, Carbon Disclosure Project, MSCI, Golman Sachs, Sustainalytics and Dow Jones Sustainability Index.

Table 2. Dimensions, items \& weights (\%) in the telecommunications sector (DJSI)

\begin{tabular}{|c|c|c|c|c|c|}
\hline & 2011 & 2012 & 2013 & 2014 & 2015 \\
\hline $\begin{array}{l}\text { Economic dimension (antitrust policy, codes of conduct/compliance/ } \\
\text { corruption \& bribery, corporate governance, privacy policy, risk \& crisis } \\
\text { management, supply chain, tax strategy, etc.) }\end{array}$ & 44 & 45 & 44 & 44 & 44 \\
\hline $\begin{array}{l}\text { Environmental dimension (climate strategy, environmental policy/ma- } \\
\text { nagement, environmental reporting, operational eco-efficiency, etc.) }\end{array}$ & 16 & 16 & 19 & 20 & 21 \\
\hline $\begin{array}{l}\text { Social dimension (corporate citizenship/philanthropy, digital inclusion, } \\
\text { labor practice indicators/human rights, Health \& safety, Social reporting, } \\
\text { stakeholder engagement, etc.) }\end{array}$ & 40 & 36 & 36 & 35 & 35 \\
\hline
\end{tabular}

Prepared by authors following Andreu, 2017

\section{Research hypothesis and methodology}

\subsection{Research hypothesis}

The quality and precision of analysts specialised in socially responsible investment has been subject to questioning, producing a crisis of confidence in the sector. The variety of evaluation systems and methodologies (Sun et al., 2011) has given rise to a multiplicity of labels and certificates and seals, making it complex for investors and other stakeholders to compare and decide between different sustainability criteria (Windolph, 2011). Consequently, it is increasingly difficult to judge whether companies focus on responsibility, sustainability, and good governance, causing a scenario of mistrust.

However, this mistrust in rating methodologies could be since they are still in their initial development stages and are often polemic. Since there are so many ways to evaluate companies' sustainable performance, and owing to the lack of homogeneous standards, there is the risk of investors losing confidence (Delmas and Blass, 2010). This makes it imperative to improve the information that will contribute both to the standardisation and credibility of sustainability ratings, even though there is lack of public information available by ESG agencies about their evaluation criteria (EscrigOlmedo et al., 2019).

In addition to the methodological criticism about sustainability indices, epistemological criticism is a factor that has not been developed in depth. Business ethics is a hybrid discipline built on the conceptual resources of several fields, including moral and political philosophy, religion, economics, sociology, and social psychology (Solomon, 1998; Epstein, 2002; Wines, 2008; Melé, 2009; Vitell, 2009). Epistemological analysis (Fernández Mateo, 2019) could also provide important resources to generate new insights on sustainability questionnaires. We are referring to subjective issues on knowledge construction and, in this case, the construction of sustainability questionnaires. From a sociological viewpoint (Berger and Luckmann, 1991), rating agencies construct a social reality with their sustainability indices. In the knowledge building process, all the factors mentioned — prejudices, definitions, variables, socioeconomic issues and interests, lack of knowledge and transparencyinteract with the social reality. The problem of the knowledge, despite its epistemological naturewhich affects understanding knowledge as a construction - has real consequences in the practice of sustainability that affects investors, companies, and rating agencies: 
Observation is determined by theories and these are composed of research postulates that can be plural or variable. Therefore, the statements of observation can be heterogeneous. In the middle of the 20th century, the philosophy of science begins to speak, not only of the fallibility of theories, but of trust or belief in research programs or paradigms. Empirical verification is determined by beliefs and concepts that are part of theories (Fernández Mateo, 2019)

Realist epistemology defends the existence of reality in and of itself and how it is, regardless of our descriptions. For anti-realist epistemology, there are many alternative schemas for discovering the world, but one cannot say that any of them are more faithful than others in the way in which things are in and of themselves. We would select some descriptions over others for their utility (Boghossian, 2009). Neopragmatism claims that attributions of reality and truth are nothing but so many obsequious promises that we make to those entities or beliefs that have surpassed the test of time, demonstrating their usefulness (Rorty, 2007).

To decrease the subjectivity of this construct (Doyle, 2018) and obtain a more objective questionnaire (Graafland et al., 2004; Eccles et al., 2014) it is important to conduct a fieldwork to assess the relevance of the items on the sustainability questionnaires. This is so because sustainability questionnaires select values and construct definitions, which open us up to a subjective world, where the only way to leave it is via intersubjectivity, which will reveal the consistency or coherence of that which is asserted as true. Averaging the results obtained via fieldwork is a methodological technique that helps to measure the materiality of the questionnaires, increasing intersubjectivity. Nonetheless, we must recognise that complete objectivity is an unattainable ideal, although progressive studies can continue to approach and improve upon it.

Today, after Rorty's critique (Moreira, 2020), it is difficult to take a stance that defends that knowledge is a transparent and neutral reflection of a reality separate from us (Fernández Mateo, 2019), although neither does it mean defending the absolutely contextual and situational nature of knowledge, dependent on a specific historical time and place (Boghossian, 2009). This latter position leads us to fragmentation of knowledge, to the construction of incommunicable individual realities, which is nothing but the situation of the ESG ratings today. Therefore, the comparison and measurement of the results obtained, and the study of their biases appear as the only tools in the quest for materiality (Eccles et al, 2012; Eccles \& Youmans, 2016; Khan et al., 2016)

From our viewpoint, the different stances of different stakeholders must be weighted to evaluate the relevance of the different criteria for measuring sustainability. The relevance is not the same for academia and investors, for instance, and one sustainability item for organisations is not equally relevant for governance. With a methodological or epistemological origin, this crisis of confidence is a reputational risk but also, as mentioned, an opportunity to improve the search for better evaluation and analysis criteria. This is particularly true about the issues that are truly relevant for companies and their stakeholders. Stakeholders' perceptions are essential for companies' performance (Parguel et al., 2011; Eccles et al., 2014) and can even threaten their survival (Chatterji et al., 2009). Identifying the material issues for a company, those that have an impact on their stakeholders and that can thus affect the value of the company itself, is decisive for good governance and CS. For this reason, the earliest studies that analysed evaluation methodologies showed that agencies and sustainability indices handled very generic topics, neglecting the sector's specific problems (Beloe et al., 2004). Given that rating agencies are the link between companies and stakeholders (Schäfer, 2005), discovering the relevance of the questions on the questionnaires is key. After discovering the cross-cutting items for all stakeholders (Academia, IBEX 35, Investors \& Regulators, NGOs, and Media), it will be easier to draft a more homogeneous and decisive questionnaire. Table 3 summarises our hypotheses. 
Table 3. Research purpose, question, and research hypothesis

\begin{tabular}{|l|l|}
\hline $\begin{array}{l}\text { Research } \\
\text { Purpose }\end{array}$ & $\begin{array}{l}\text { To find out if all variables included in the corporate governance dimension on the sustainability } \\
\text { indexes are equally relevant for CSR and CG. The variation would demonstrate a different impact } \\
\text { and materiality (Khan et al, 2016). }\end{array}$ \\
\hline $\begin{array}{l}\text { Research } \\
\text { Question }\end{array}$ & $\begin{array}{l}\text { What are the most relevant items and dimensions both for CG and CSR? What new questions } \\
\text { should appear in the questionnaires? }\end{array}$ \\
\hline $\begin{array}{l}\text { Research } \\
\text { Hypothesis }\end{array}$ & $\begin{array}{l}\text { It is plausible that, given the bibliographical proof (Fowler and Hope 2007; Donker and Zahir, 2008; } \\
\text { Delmas and Blass, 2010; Beloe et al., 2004; Windolph, 2011, Andreu et al., 2018), not all the items } \\
\text { included in the corporate governance dimension of sustainability indices are homogeneous and in- } \\
\text { terchangeable and, therefore, equally relevant. Thus, we conjecture, as a research hypothesis, that } \\
\text { there are items with more relevance and impact than other items. Is this hypothesis true? }\end{array}$ \\
\hline
\end{tabular}

Source: Prepared by authors (2018)

\subsection{Methodology}

A series of groups were defined to receive the questionnaire and give different answers depending on their skills and knowledge in the field. Concretely, these groups were: IBEX 35, NGOs, Academia, Regulators \& Investors and Media. These groups would entail each person who answered the questionnaire being assigned to one of these groups. These experimental groups cannot aspire to being representative samples of the population, but a qualitative criterion is included here based on the experience, knowledge and capacities of the individuals taking part in the study. Namely, it is an intentional sampling (Jensen, 2013). Qualitative research is particularly useful for exploring implicit assumptions, abstract concepts, and operational definitions (Ricart et al., 2005).

On the first two parts of the questionnaire, those surveyed would be surveyed to rate each of the 65 variables from 1 to 10 (where 1 is least and 10 greatest) with regard to the impact each of them has on the quality of CG and the development of CS policies.

Pre-launch and comparison: From 3 to 9 October 2016. When the final version of the questionnaire was nearly ready, a test phase was opened, commonly known as the pretest. Prior to the questionnaire's general launch, people part of the focus group were surveyed, by way of pretest to fill out the questionnaire so general feedback could be obtained to verify the concrete understanding of the questions and that the URL worked properly.

Launch of questionnaire: 10 October 2016. After the pretest was conducted, a database was readied of 217 individuals to build the research sample. Further, Spainsif was asked to distribute the questionnaire among its members to expand the scope of the sample. Spainsif (Spanish Sustainable Investment Forum) is an association comprised of different stakeholders whose essential mission is to foster the integration of environmental, social and good corporate governance criteria in investment policies in Spain via dialogue with the different social groups and contributing to sustainable development. The association aims to be a platform for meeting and reference to produce and disseminate knowledge on socially responsible investment, as well as raising awareness and driving forward changes in investment processes among the investment community, the public administration, companies and citizens as a whole.

This sample was made up of individuals selected based on qualitative criteria sufficiently relevant to form part of the analysis units: a criterion for statistical representativeness is not followed, but instead more for substantive representativeness, with the purpose of covering all social situations of primary interest for the research project, more than an aim to reproduce the characteristics of the entire population. Further, with the aim of not biasing the responses, the people who had been part 
of the discussion and pretest group, although not the organisations they represented, were excluded from the general mailing, to prevent the people who had helped configure the new questions from participating in the constructed object. It is about overcoming the epistemological problem of the interaction between subject and object.

To process all the information, the average was calculated, one of the measurements possible for central tendencies (Jensen, 2013). By using the average of all responses as a cut-off criterion, an initial discrimination was done of the relevance of the 65 items on the questionnaire. The average, as a cut-off criterion, lets exclusively those items be considered relevant on the questionnaire that:

1. Are greater than or equal to the average on each of the CG and CSR questions.

2. Are above the average value for at least one of the groups surveyed. This last weighting is inspired by the Likert scale (Likert, 1931), a scale created as the simple sum or average of individual items - Likert scaling assumes distances between each group are equal. Given that the definition of the relevance of each of the dimensions was done quantitatively - the issues above the average - the results are both defined and scalable.

According to this criterion, an item that, for example, is greater than the average relevance on the CG or CSR dimensions, and exceeds the average in the IBEX and MEDIA groups, would obtain a score of $2 / 5$. Continuing with the same example, an item that is higher than all averages in all groups surveyed (and in CSR and CG) would have a score of $5 / 5$ and, consequently, would be considered a determinant item, as indeed happens. Following the same logic and being rigorous with the criterion, an item that is not greater than or equal to the average score on either of the two variables submitted to research (CG and CSR) would be considered not relevant and, consequently, outside the scope of any relevance analysis.

\section{Analysis of data obtained}

The main conclusions that can be drawn from Table 4 .

Level 5: determinant (5/5): Above the average in the 5 groups studied. The most noteworthy items in this level can be summarised by these points:

- Almost all items that appear in this level (except one, (7.3) 'Transparency of taxes paid by countries') are in the category 'Bribery, corruption and money laundering'. Further: all items included in this category on the questionnaire ( 9 out of 9 ) passed the cut-off criterion for the average in all groups investigated.

- Only one of them, (6.8) 'Transparency in charitable donations and sponsorships with public institutions' does not appear in level 5, but in level 4.

- The most relevant item is (6.2) 'Drafting of a policy to fight bribery and corruption', an item that was already being surveyed on indexes by analysts including EIRIS, SUSTAINALYTICS and ROBECOSAM on the DJSI.

- Finally, we should also point out that 9 items included in level 5, six are questions that were already being surveyed on the sustainability indexes most used by companies ( $\mathrm{PwC} \&$ Corporate Excellence, 2013; Andreu et al., 2018), two were reformulated and expanded by our study, and one was provided ex novo for this research. The rewritten items (by order of relevance) are: ‘

- (6.7) 'Transparency of payments to political parties and the foundations that report to them, to the media and to unions, and these payments' compliance with the law' 
Table 4. Analysis obtained in order of relevance

The first number following each item is this item's relevance for corporate governance (total average) and
the second number is the relevance level for CSR (total average). In normal font items currently included in
sustainability indexes; Bold type items not currently included in the sustainability indexes but identified via the
focus group and other instruments and italics, reformulated items considered new for this research.
Andreu, Fernández \& Fernández (2018) study “A critical review of the Corporate Governance dimension in the
Sustainability Indexes questionnaires" contains the research questionnaire to read the complete literal text of
all questions without relevance dimension analysis.

LEVEL 5

\begin{tabular}{|l|l|l|l|l|l|l|l|l|}
\hline 6.2 Bribery and corruption: mitigation policy & 9.2 & 9 & $\checkmark$ & $\checkmark$ & $\checkmark$ & $\checkmark$ & $\checkmark$ & 5 \\
\hline 6.3 Money laundering: policy & 9.2 & 9 & $\checkmark$ & $\checkmark$ & $\checkmark$ & $\checkmark$ & $\checkmark$ & 5 \\
\hline 6.7 Payments to political parties and foundations & 9.2 & 9 & $\checkmark$ & $\checkmark$ & $\checkmark$ & $\checkmark$ & $\checkmark$ & 5 \\
\hline 6.1 Bribery and corruption: exposure level & 9.1 & 9 & $\checkmark$ & $\checkmark$ & $\checkmark$ & $\checkmark$ & $\checkmark$ & 5 \\
\hline $\begin{array}{l}\text { 6.9 Public procurement: procedures to delimit } \\
\text { responsibilities }\end{array}$ & 9.2 & 8.8 & $\checkmark$ & $\checkmark$ & $\checkmark$ & $\checkmark$ & $\checkmark$ & 5 \\
\hline $\begin{array}{l}\text { 6.4 Bribery, corruption, laundering: management } \\
\text { programme }\end{array}$ & 9 & 8.9 & $\checkmark$ & $\checkmark$ & $\checkmark$ & $\checkmark$ & $\checkmark$ & 5 \\
\hline $\begin{array}{l}\text { 6.6 Existence of whistle-blowing channels } \\
\text { 7.3 Taxes paid by country }\end{array}$ & 8.9 & 8.8 & $\checkmark$ & $\checkmark$ & $\checkmark$ & $\checkmark$ & $\checkmark$ & 5 \\
\hline 6.5 Incidents with Code of Ethics & 8.7 & 8.6 & $\checkmark$ & $\checkmark$ & $\checkmark$ & $\checkmark$ & $\checkmark$ & 5 \\
\hline
\end{tabular}

LEVEL 4

\begin{tabular}{|l|c|c|c|c|c|c|c|c|}
\hline 7.10 Tax havens: activity report & 9 & 8.8 & $\checkmark$ & $\checkmark$ & & $\checkmark$ & $\checkmark$ & 4 \\
\hline $\begin{array}{l}\text { 5.2 Code of Ethics: mechanisms to assure } \\
\text { compliance }\end{array}$ & 8.9 & 8.7 & $\checkmark$ & $\checkmark$ & & $\checkmark$ & $\checkmark$ & 4 \\
\hline 7.8 Fiscal policy: responsibility & 9 & 8.6 & $\checkmark$ & $\checkmark$ & & $\checkmark$ & $\checkmark$ & 4 \\
\hline 2.3 CSR policy: Board responsibility & 8.6 & 8.8 & $\checkmark$ & & $\checkmark$ & $\checkmark$ & $\checkmark$ & 4 \\
\hline 5.1 Code of Ethics: scope & 8.8 & 8.6 & $\checkmark$ & $\checkmark$ & & $\checkmark$ & $\checkmark$ & 4 \\
\hline
\end{tabular}

\section{LEVEL 3}

\begin{tabular}{|l|l|l|l|l|l|l|l|l|}
\hline 4.2 Risk management: definition / identification & 8.6 & 8.8 & $\checkmark$ & $\checkmark$ & & & $\checkmark$ & 3 \\
\hline 5.4 Code of Ethics: clarity of penalty system & 8.9 & 8.5 & & $\checkmark$ & & $\checkmark$ & $\checkmark$ & 3 \\
\hline 1.3 Remuneration: transparency and coherence & 8.9 & 8.4 & $\checkmark$ & $\checkmark$ & & & $\checkmark$ & 3 \\
\hline 7.7 Competition standards & 8.8 & 8.4 & $\checkmark$ & & & $\checkmark$ & $\checkmark$ & 3 \\
\hline 4.1 Risk management: responsible & 8.6 & 8.6 & $\checkmark$ & $\checkmark$ & & & $\checkmark$ & 3 \\
\hline
\end{tabular}




\begin{tabular}{|c|c|c|c|c|c|c|c|c|}
\hline 5.5 Promotion of ethical culture & 8.5 & 8.7 & & $\checkmark$ & $\checkmark$ & & $\checkmark$ & 3 \\
\hline $\begin{array}{l}\text { 7.6 Transparency of final sentences and } \\
\text { competition fines }\end{array}$ & 8.7 & 8.5 & $\checkmark$ & & & $\checkmark$ & $\checkmark$ & 3 \\
\hline 7.9 Fiscal policy: transparency & 8.7 & 8.5 & $\checkmark$ & & & $\checkmark$ & $\checkmark$ & 3 \\
\hline $\begin{array}{l}\text { 6.8 Donations to and sponsorships of public } \\
\text { institutions }\end{array}$ & 8.6 & 8.5 & & & $\checkmark$ & $\checkmark$ & $\checkmark$ & 3 \\
\hline 2.4 Proposal and values: transparency & 8.4 & 8.6 & $\checkmark$ & $\checkmark$ & $\checkmark$ & & & 3 \\
\hline 3.5 Independence of Risk Committee & 8.6 & 8.4 & $\checkmark$ & & $\checkmark$ & & $\checkmark$ & 3 \\
\hline 3.15 Existence of compliance division & 8.7 & 8.3 & & $\checkmark$ & $\checkmark$ & $\checkmark$ & & 3 \\
\hline 3.14 Stakeholders' long-term interest & 8.3 & 8.5 & $\checkmark$ & & $\checkmark$ & $\checkmark$ & & 3 \\
\hline \multicolumn{9}{|l|}{ LEVEL 2} \\
\hline 2.6 Human rights: due diligence / remedy & 8.3 & 9.1 & $\checkmark$ & & $\checkmark$ & & & 2 \\
\hline $\begin{array}{l}\text { 3.6 Independence of Remuneration and } \\
\text { Appointments Committee }\end{array}$ & 9 & 8.3 & & $\checkmark$ & $\checkmark$ & & & 2 \\
\hline 1.2 Transparency of Board operations & 8.9 & 8.3 & & $\checkmark$ & & $\checkmark$ & & 2 \\
\hline 5.3 High risk countries: breakdown & 8.4 & 8.7 & $\checkmark$ & & & $\checkmark$ & & 2 \\
\hline $\begin{array}{l}\text { 3.10 Independence of Board members: } \\
\text { guarantee procedure }\end{array}$ & 8.8 & 8.1 & & $\checkmark$ & $\checkmark$ & & & 2 \\
\hline 3.7 Board diversity & 8.4 & 8.4 & & & $\checkmark$ & $\checkmark$ & & 2 \\
\hline 1.4 Remuneration: CSR criteria & 7.7 & 8.8 & $\checkmark$ & & $\checkmark$ & & & 2 \\
\hline 7.5 Transparency of ongoing legal processes & 8.4 & 8.1 & $\checkmark$ & & & $\checkmark$ & & 2 \\
\hline \multicolumn{9}{|l|}{ LEVEL 1} \\
\hline 4.4 ESG risks: management system & 8.3 & 8.9 & & $\checkmark$ & & & & 1 \\
\hline 4.5 ESG risks: definition & 8.3 & 8.9 & $\checkmark$ & & & & & 1 \\
\hline 2.5 Supply chain: transparency / supervision & 8.1 & 8.9 & $\checkmark$ & & & & & 1 \\
\hline 3.13 Shareholders' long-term interest & 8.7 & 8.1 & $\checkmark$ & & & & & 1 \\
\hline 3.3 Independence of Board members & 8.7 & 8 & & $\checkmark$ & & & & 1 \\
\hline 7.4 Incidents with public policies & 8.3 & 8.2 & & & & $\checkmark$ & & 1 \\
\hline 2.2 CSR reporting: quality & 7.8 & 8.6 & & & $\checkmark$ & & & 1 \\
\hline 3.8 Minority shareholders: defence policy & 8.6 & 7.7 & & & $\checkmark$ & & & 1 \\
\hline 5.7 Code of Ethics: basic indicators & 8.1 & 8.2 & & $\checkmark$ & & & & 1 \\
\hline 4.3 Risk management: transparent methodology & 8.1 & 8.1 & & & & $\checkmark$ & & 1 \\
\hline
\end{tabular}


- (6.6) 'Existence of independent whistleblowing channels (external company) and guarantee of anonymity. Procedures to guarantee the independence of whistleblowing channels'

- The new item provided by the research is (6.9) 'Procedure to delimit responsibilities for poor practices in procurement and public tender procedures'

Level 4: extremely relevant (4/5), above the average in 4 groups researched. The most noteworthy items in this level can be summarised by these points:

- Of the five items that appear in this level, three were already being surveyed in sustainability indexes and two are new contributions from this research. These new items are (from greatest to least relevance):

- (7.10) 'Information on activities in territories considered tax havens or with risk of tax evasion activities',

- (7.8) 'Fiscal policy: responsibility'. Namely, introducing the fiscal impact as a new itemand at level 4 - is one of the main contributions of this research.

- Another especially important item is item (2.3) 'Board of directors responsible for the company's CSR policy and strategy' - which was already being surveyed by analysts and indexes including EIRIS, GOLDMAN SACHS, SUSTAINALYTICS and ROBECOSAM/ DJSI - did not score above the average by the IBEX 35 group and, consequently, does not have a high enough relevance level for this group. For the purposes of this research, this information is relevant since:

- From a theoretical approach, the fact that the IBEX 35 does not consider this topic a determinant $5 / 5$ category raises doubts on the assimilation of their responsibility on this topic. If the CSR/CS policy is the non-delegable function of the board of directorsArticle 529, three 1 (a) of the Spanish Corporations Act (Official Spanish Gazette, BOE, 2014) — and if '(T)he company will promote a suitable corporate social responsibility policy'-Principle 24 of the Good Governance Code for Listed Companies (CNMV, 2015) - it is valid to interpret the fact as worrisome that those who have to take nondelegable responsibility for this function and approve the CSR policy, do not consider this item under their responsibility as relevant.

Level 3: extremely relevant (3/5), above the average in 3 groups researched. The most noteworthy items in this level can be summarised by these points:

- This is the level in which there are the highest number of items, 13, and where our research provides the highest number of new items, up to nine. From greatest to least relevance, they are:

- (5.4) 'Clarity of corporate penalty system for noncompliance with the directives of the Code of Ethics'

- (7.7) 'Procedure to delimit responsibilities for noncompliance with the rules of competition'

- (5.5) 'Promotion of an ethical culture among employees beyond formal compliance systems with the code and incorporation of its principles in the formal decision-making process' ${ }^{2}$.

\footnotetext{
${ }^{2}$ For example, some companies define a battery of harsh questions that all of its executives must ask themselves before making decisions: What newspaper headline would you not want to see if you made this decision? or How could you explain this decision to your family, especially your children? or Is this decision compromising in the long term, although it may be beneficial in the short term?
} 
- (7.6) 'Transparency of final convictions for the company in legal and/or administrative processes (including those linked to collusive competitive practices), their associated fines and, where applicable, for prison sentences of its executives, if there are any'

- (7.9) 'Transparency of the company's fiscal policy and intragroup operations with possible consequences from a fiscal perspective (prices, loans...)'

- (6.8) 'Transparency in charitable donations and sponsorships with public institutions'

- (2.4) 'Transparency and clarity of the purpose (vision) of the organisation and its values'

- (3.15) 'Existence of a compliance area, which reports to the board, to ensure compliance with the law, the spirit of the law and internal and external commitments and affairs publicly taken on by the company'

- (3.14) 'Alignment of the incentives structure with long-term stakeholders' interests'

- Another aspect meriting mention is that, among the top three levels of relevance $(5,4$ and 3 ), the research provides 14 new items, compared to the 13 that were already being surveyed until now on sustainability indexes.

Level 2: extremely relevant (2/5), above the average in 2 groups researched. The most noteworthy items in this level can be summarised by these points:

- Of the nine items at this level, only three are new:

- (2.6) 'Transparency of the policy to respect human rights (application of due diligence and remedy access systems and mechanisms)', which is also the most relevant at this level

- (3.10) 'Procedures to ensure the independence of Board members, of the main committees reporting to the Board and the decisions made by independent Board members (to prevent reprisals)

- (7.5) 'Transparency of judicial and/or administrative processes opened on the company (including those linked to collusive competitive practices) and provisions made to cover possible fines or penalties stemming from these processes'

- Lastly, recall that four of the nine items that appear in this level 2 are those from the category 'Board structure and operation', namely the items that have traditionally been linked to the core of corporate governance:

- (3.4) 'Independence of the Audit Committee'

- (3.6) 'Independence of the Remuneration Committee and Appointments Committee'

- (3.10) 'Procedures to ensure the independence of Board members, of the main committees reporting to the Board and the decisions made by independent Board members (to prevent reprisals)'

- (3.7) 'Board diversity (we define diversity broadly: gender, cultures, generation/age, disabilities...)'. 
Level 1: not very relevant (1/5), above the average in 1 group researched. The most noteworthy items in this level can be summarised by these points:

- Of the 10 items in this level, seven were already being surveyed and three are new:

- (2.5) 'Transparency of the supply chain policy and supervision procedures'

- (3.13) 'Procedures to ensure actions in the interests of long-term shareholders (Examples: clawback clauses via which executives are obliged to return bonuses if in the medium to long term - three to five years - their decisions harm shareholders' interests)'

- (5.7) 'Transparency of basic indicators associated with the Code of Ethics (personnel trained, coursed done, penalties imposed, perception of ethical culture by employees, engagement indicator...)'

- It is notable that item (2.2) 'Quality of CSR reporting (num. of years reported, data verified externally, quality of data reported, etc.), which is one of the activities to which companies devote the most time and resources and that has, in some way, become an identifying trait of CSR/CS, appears at level 1 (the least relevant) and that it was only higher than the cut-off average in the NGO group.

- It also stands out that item (4.3) 'Transparency of the methodology used to mitigate company risks', which has also been an important feature for showcasing good CSR/CS practices, only exceeded the cut-off average for relevance in the media group.

\section{Items that ended up outside the ranking of most relevant}

Table 5 shows the breakdown of the items considered relevant and irrelevant for our research depending on their origin: those that were already being surveyed on the indexes most employed by companies (PwC \& Corporate Excellence, 2013; Andreu et al., 2018) and those resulting from this research.

Table 5. Comparison of old items versus new items considered relevant and irrelevant in our research

\begin{tabular}{|l|c|c|c|}
\hline Considered relevant in this research & $\begin{array}{c}\text { Items currently } \\
\text { surveyed }\end{array}$ & $\begin{array}{c}\text { New items arising } \\
\text { from research }\end{array}$ & TOTAL \\
\hline NOT considered relevant in this research & 25 & $20^{3}$ & 45 \\
\hline TOTAL & $\mathbf{3 2}$ & $\mathbf{3 2}$ & $\mathbf{6 4}$ \\
\hline
\end{tabular}

Prepared by authors, 2019

\footnotetext{
${ }^{3}$ The PwC and Corporate Excellence document (2013) started with the inclusion of two items (whistleblowing channel and payments to political parties). When submitted to comparison in the focus group and individual interviews, as well as the revision of new sources, material issues were rewritten by the researcher. For this reason, they have been classified as new items for the purpose of research results
} 
Table 6 shows items not considered relevant in this research (most to least relevant):

Table 6. List of items discarded due to their lack of relevance (sorted by ranking, average score)

\begin{tabular}{|c|c|c|c|c|c|c|c|c|}
\hline \multicolumn{9}{|c|}{$\begin{array}{l}\text { The first number following each item is this item's relevance for corporate governance (total average) and } \\
\text { the second number is the relevance level for CSR (total average). In normal font items currently included in } \\
\text { sustainability indexes; Bold type items not currently included in the sustainability indexes but identified via the } \\
\text { focus group and other instruments and italics, reformulated items considered new for this research. } \\
\text { Andreu, Fernández \& Fernández (2018) study "A critical review of the Corporate Governance dimension in the } \\
\text { Sustainability Indexes questionnaires" contains the research questionnaire to read the complete literal text of } \\
\text { all questions without relevance dimension analysis. }\end{array}$} \\
\hline & 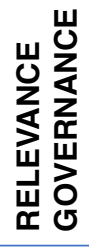 & 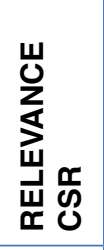 & 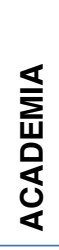 & 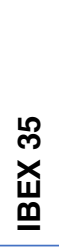 & $\begin{array}{l}\text { o } \\
\text { Oర } \\
\text { z }\end{array}$ & 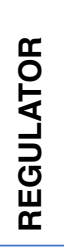 & $\begin{array}{l}\overleftarrow{\Delta} \\
\stackrel{\amalg}{\Sigma}\end{array}$ & 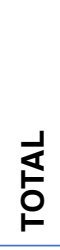 \\
\hline $\begin{array}{l}\text { 1.5 Decisions: Documentary records } \\
\text { (governance and management) }\end{array}$ & 8.7 & 8.2 & - & - & - & - & - & 0 \\
\hline 2.8 Positive impact: impact indicators & 7.9 & 8.7 & - & - & - & 0 & 0 & 0 \\
\hline 3.9 Shareholder participation in general meeting & 8.6 & 7.9 & - & - & - & - & - & 0 \\
\hline $\begin{array}{l}\text { 3.17 Publication of senior mgmt. organisation } \\
\text { chart }\end{array}$ & 8.6 & 7.9 & - & - & - & - & - & 0 \\
\hline 4.6 Corporate governance incidents & 8.5 & 8.1 & - & - & - & - & - & 0 \\
\hline 4.7 Risk: maximum acceptable level & 8.2 & 8.3 & - & - & - & - & - & 0 \\
\hline 4.9 Criminal risks map & 8.6 & 7.9 & - & - & - & - & - & 0 \\
\hline 5.6 Corporate culture diagnostic & 8.2 & 8.4 & - & - & - & - & - & 0 \\
\hline 2.7 ESG criteria in product design & 7.6 & 8.7 & - & - & - & - & - & 0 \\
\hline 3.16 Delegation of Authorities Protocol & 8.4 & 7.9 & - & - & - & - & - & 0 \\
\hline $\begin{array}{l}\text { 4.8 Risk supervision and control: } \\
\text { responsibility Audit Committee }\end{array}$ & 8.4 & 8 & - & - & - & - & - & 0 \\
\hline $\begin{array}{l}\text { 3.12 Compliance / Good Governance Code: } \\
\text { compliance audit }\end{array}$ & 8.3 & 7.8 & - & - & - & - & - & 0 \\
\hline 3.1 Separation of Chairman and CEO & 8.4 & 7.6 & - & - & - & - & - & 0 \\
\hline $\begin{array}{l}\text { 3.11 Board operation: assessment third } \\
\text { independent party }\end{array}$ & 8.4 & 7.6 & - & - & - & - & - & 0 \\
\hline 2.1 Commitment: Formalisation & 7.4 & 8.4 & - & - & - & - & - & 0 \\
\hline 3.2 Lead Independet Director & 8 & 7.3 & - & - & - & - & - & 0 \\
\hline 7.2 Regulators: dialogue and participation activity & 7.8 & 7.8 & - & - & - & - & - & 0 \\
\hline 7.1 Public policies: positioning & 7.4 & 7.5 & - & - & - & - & - & 0 \\
\hline 1.1 Fees ratio: Audit vs not auditing & 6.6 & 7 & - & - & - & - & - & 0 \\
\hline
\end{tabular}


- We must clarify that all items included in the category 'Bribery, corruption and money laundering' on the questionnaire ( 9 out of 9) were higher than the relevance cut-offline for all groups investigated. Further, all items appear in level 5 of relevance, except for (6.8) 'Transparency of charitable donations and sponsorships with public institutions', which appears in level 4, only one down.

- Seven old items and 12 new items were discarded. This five-item difference suggests that both bibliographical reviews and the focus group and individual interviews would perhaps have gone further than what is demanded by the market. The sample of this research, composed by professors, experts, specialised journalists and members of the top management with a direct and in-depth vision - that places them in a privileged position - could have led to biases by adding an excessive number of new items in the study.

- Regarding the 'flagship' items on Corporate Governance, there are two situations that merit mention. On the one hand, particularly noteworthy is that item (1.1) 'Ratio of non-audit fees to audit fees', which is one of the main measures to favour corporate governance, ranked in last place among the 65 items in our study and, consequently, was not considered a relevant item. On the other - and without such a low position, although also discarded as a relevant item — standing out is item (3.2) 'Existence of a Lead Independent Director', another relevant idea for the world of corporate governance.

\section{Discussion}

The sample for the study and its analysis was completed in 2017. It was a qualified sample, experts with extensive knowledge in the field. Why this analysis is still relevant today? If we look at the practices of Spanish companies, and according to the results of the CSR Observatory Report: analysis of the year 2018 - published in 2020 - the areas with the lowest level of transparency are human rights, corruption and taxation. The obligation established in the Spanish Law 11/2018 on non-financial information and diversity has led to an improvement in CSR information with respect to previous years. However, the information provided by the companies is focused on business achievements and good practices, far from the objective of accountability sought by the Law.

The score obtained by the companies analysed in terms of corruption 'has an average of 24.13 out of 100 possible points, compared to 20.24 points in 2017. This is the dimension that obtains the second worst average score only behind human rights' (Vázquez, 2020: 146). The best positioned sector 'is the Oil and Energy sector with an average score of 39.64 points. The sector with the lowest score is Financial Services and Real Estate with an average rating of 15.88 points out of 100' (2020: 147).

Table 7. CSR in the IBEX 35 annual reports: corruption dimension

Of the 35 companies analysed, 17 have a specific public policy (or similar document) on corruption. Of the remaining 18, only one provides a clear and reasoned justification for its absence. (2020: 153)

Only 5 of the 35 companies report specific corruption risks identified from the assessment processes in this area. The remaining companies limit themselves to mentioning compliance or integrity risks, which sometimes include corruption and bribery, without detailing the forms that this can take depending on the type of activities that the company carries out. (2020: 157)

In the analysis, 9 companies out of 35 provide information on the existence of a control audit system around corruption (2020:180). None of the 35 companies provide satisfactory information on the results of the anticorruption audit, let alone on the actions taken as a result of the audit (2020: 181) 
These prove the reliability of the field work. All groups surveyed through qualitative and quantitative research-Academia, Ibex 35, Media, NGOs, Investors \& Regulators-state the relevance of the category Bribery Corruption and Money Laundering (6). The highest scoring variables were and (6.2) 'Bribery and corruption: mitigation policy' and (6.3) 'Money laundering: policy'. The weight of the questions that comprise the questionnaire in the category of Bribery, Corruption and Money Laundering represents $95.55 \%$. It is a decisive category (see Graph 1).

Corruption is one of the areas with the lowest degree of transparency in the CSR Observatory Report in line with the results of the research. Therefore, not all areas of the governance dimension of a sustainability index require the same attention, improvement, and correction. Consequently, there may be a greenwashing effect-'a legitimation strategy that occurs when firms voluntarily issue CSR Reports to promote an impression of legitimate social and environmental values, which may or may not be substantiated' (Mahoney et al., 2013: 352) — that overshadows the relevance of improving this fundamental dimension: anti-corruption policies. If Spanish companies want to contribute to the achievement of the SDG, rather than worrying about less material aspects, they should start paying greater attention to the variables that can be deduced from the anti-corruption dimension, which connects with ODS 16:

- 16.5 'Substantially reduce corruption and bribery in all their forms' and

- 16.6 'Develop effective, accountable and transparent institutions at all levels'

Graph 1. Weight of questions (in \%) above the cut-offline with regard to total questions on the questionnaire for each category

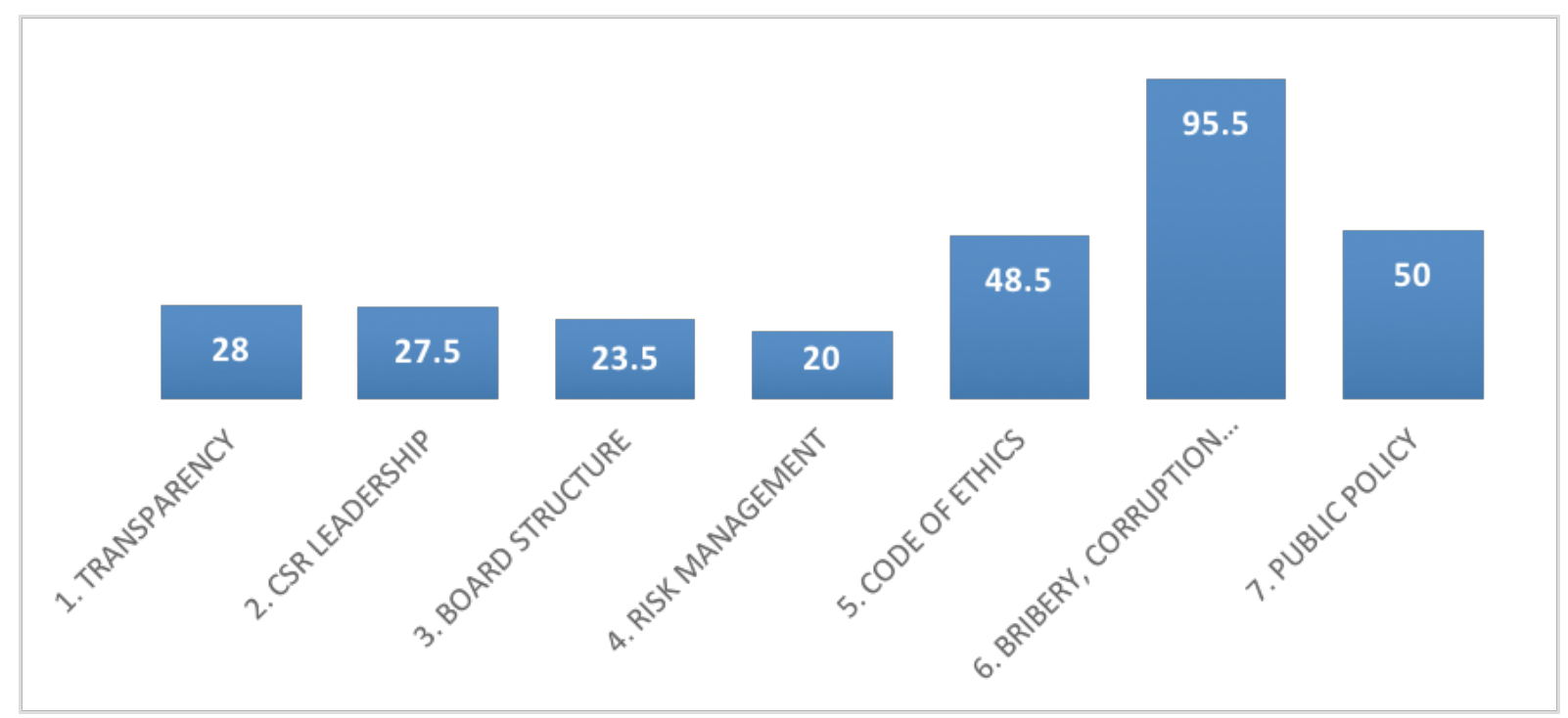

Prepared by authors, following Andreu, 2017

This study has revealed that although code of ethics is fundamental for CSR/CS - requiring more implementation mechanisms, self-regulation methods, control, and punishment mechanisms - the anti-corruption policy have a decisive role to play. According to the results, that there is not full awareness of its relevance. To become aware of this problem, activist NGOs would fulfil the function of proxy advisors. However, this role has little weight in our country. Corporate political activismpresent in donations, lobbying and other types of political corruption - would be used to resist 'socialoriented shareholder pressure' (Hadani et al., 2018). This problem would lead us to studying the 'dark side' of institutional environment in which companies operate. Corporate governance systems depend 
on the institutional environments, a set of formal and informal rules that will model governance practices and, in short, their 'corporate culture' (Jackson \& Apostolakou, 2010).

\section{Conclusions}

The sustainability indexes have played a role in closing the gap between CSR/CS and CG. In fact, some empirical research has demonstrated the crucial role of CG in CSR. The purpose of this study has been to assess the different items present in the corporate governance dimension of the sustainability indexes. In other words, to discover their true materiality. If we want to have a real picture of the core elements for CSR it is necessary to recognise the fundamental elements to avoid greenwashing policies. The high recognition of other items, included in the governance dimension, can generate a false picture of reality.

The questions on sustainability indexes do not represent a static reality. The analysis of relevance of sustainability indexes offers new meanings, guiding the decisions of senior management. Sustainability is a construct, a multidimensional reality that should be assessed in terms of the materiality of the components, both for companies and society. This construct, the result of a dialogue between different institutions and stakeholders, changes over time. For this reason, the questions and their relevance also change. The digital transformation - the so-called fourth industrial revolution - has given rise to new concerns about privacy and the use of personal information. This scenario can lead to the inclusion of new questions on the governance dimension.

\section{References}

Adam, A. M. y Shavit, T. (2008). How can a ratings-based method for assessing corporate social responsibility (CSR) provide an incentive to firms excluded from socially responsible investment indexes to invest in CSR? Journal of Business Ethics, 82(4), 899-905. https://doi.org/10.1007/s10551-007-9600-4

Aguilera, R. V., Williams, C. A., Conley, J. M., \& Rupp, D. E. (2006). Corporate governance and social responsibility: A comparative analysis of the UK and the US. Corporate Governance: an international review, 14(3), 147-158. https://doi.org/10.1111/j.14678683.2006.00495.x

Andreu, A. (2017). Revisión crítica de la dimensión "Gobierno Corporativo" en los Índices de Sostenibilidad: análisis del ejercicio de la responsabilidad del Consejo de Administración en materia de RSC en las compañías del Ibex 35 español. Tesis doctoral. Madrid. Universidad Pontificia Comillas.

Andreu, A., Fernández, J. L., \& Fernández, J. (2018). Revisión crítica de la dimensión Gobierno Corporativo en los cuestionarios de los Índices de Sostenibilidad. Revista de Comunicación, 17(2). https://doi.org/10.26441/rc17.2-2018-a1

Avetisyan, E., \& Hockerts, K. (2017). The consolidation of the ESG rating industry as an enactment of institutional retrogression. Business Strategy and the Environment, 26(3), 316-330. https://doi.org/10.1002/bse.1919

Baas, R. B., Georgakopoulos, G., Vasileiou, K. Z., \& Sotiropoulos, I. (2016). An Investigation of Corporate Sustainability Value to Investors Before and After the Financial Crisis. International Journal of Economics and Finance, 8(6), 37. http://dx.doi.org/10.5539/ijef.v8n6p37 
Barreiro-Gen, M., Lozano, R., \& Zafar, A. (2020). Changes in Sustainability Priorities in Organisations due to the COVID-19 Outbreak: Averting Environmental Rebound Effects on Society. Sustainability, 12(12), 5031. https://doi.org/10.3390/su12125031

Beloe, S., Scherer, J., \& Knoepfel, I. (2004). Values for money: reviewing the quality of SRI research. SustainAbility. http://sustainability.com/our-work/reports/values-for-money/

Beltratti, A. (2005). The complementarity between corporate governance and corporate social responsibility. The Geneva Papers on Risk and Insurance-Issues and Practice, 30(3), 373-386. https://doi.org/10.1057/palgrave.gpp.2510035

Berger, P. L., \& Luckmann, T. (1991). The social construction of reality: A treatise in the sociology of knowledge. England. Penguin Books.

Bird, F. (2001). Good governance: A philosophical discussion of the responsibilities and practices of organizational governors. Canadian Journal of Administrative Sciences/Revue Canadienne des Sciences de l'Administration, 18(4), 298-312. https://doi.org/10.1111/j.1936-4490.2001.tb00265.x

BlackRock (2016). “Exploring ESG: A Practitioner's Perspective”. September 2016. Black Rock. https://www.blackrock.com/investing/literature/whitepaper/viewpoint-exploring-esg-apractitioners-perspective-june-2016.pdf

Blair, M. M. (1996). Ownership and control: Rethinking corporate governance for the twenty-first century. Long Range Planning, 3 (29), 432. https://doi.org/10.1016/0024-6301(96)90031-X

Boghossian, P. (2007). Fear of knowledge: Against relativism and constructivism. Oxford. Oxford University Press.

Chan, M. C., Watson, J., \& Woodliff, D. (2014). Corporate governance quality and CSR disclosures. Journal of Business Ethics, 125(1), 59-73. https://doi.org/10.1007/s10551-013-1887-8

Chatterji, A. K., Levine, D. I., \& Toffel, M. W. (2009). How well do social ratings actually measure corporate social responsibility? Journal of Economics \& Management Strategy, 18(1), 125-169. https://doi.org/10.1111/j.1530-9134.2009.00210.x

CNMV (2015). Código de buen gobierno de las sociedades cotizadas. Comision Nacional del Mercado de Valores (CNMV). https://www.cnmv.es/docportal/publicaciones/codigogov/codigo buen_gobierno.pdf

Dahlsrud, A. (2008). How corporate social responsibility is defined: an analysis of 37 definitions. Corporate social responsibility and environmental management, 15(1), 1-13. https://doi. org/10.1002/csr.132

De la Cuesta, González, M., Pardo, E., \& Paredes, J. D. (2015). Identificación de indicadores relevantes del desempeño RSE mediante la utilización de técnicas multicriterio. Innovar, 25(55), 75-88. https://doi.org/10.15446/innovar.v25n55.47197

Delmas, M., \& Blass, V. D. (2010). Measuring corporate environmental performance: the tradeoffs of sustainability ratings. Business Strategy and the Environment, 19(4), 245-260. https://doi.org/10.1002/bse.676

Donker, H., \& Zahir, S. (2008). Towards an impartial and effective corporate governance rating system. Corporate Governance: The international journal of business in society, 8(1), 83-93. https://doi.org/10.1108/14720700810853428 
Doyle, T. (2018) Ratings that don't rate. The subjective world of ESG ratings agencies. American Council for Capital Formation. http://accf.org/2018/07/19/ratings-that-dont-rate-the-subjectiveworld-of-esg-ratings-agencies/

Eccles, R. G., Krzus, M. P., Rogers, J., \& Serafeim, G. (2012). The need for sector-specific materiality and sustainability reporting standards. Journal of Applied Corporate Finance, 24(2), 65-71. https://doi.org/10.1111/j.1745-6622.2012.00380.x

Eccles, R. G., Ioannou, I., \& Serafeim, G. (2014). The impact of corporate sustainability on organizational processes and performance. Management Science, 60(11), 2835-2857. https://doi.org/10.3386/w17950

Eccles, R. G., \& Youmans, T. (2016). Materiality in corporate governance: The statement of significant audiences and materiality. Journal of Applied Corporate Finance, 28(2), 39-46. https://doi.org/10.1111/jacf.12173

Elkington, J. (2006), “Governance for sustainability", Corporate Governance: An International Review, Vol. 14 No. 6, pp. 522-9. https://doi.org/10.1111/j.1467-8683.2006.00527.x

Epstein, E. M. (2002). Religion and business-the critical role of religious traditions in management education. Journal of Business Ethics, 38(1-2), 91-96. https://doi. org/10.1023/A:1015712827640

Escrig, E., Fernández, M. A., \& Muñoz, J. M. (2010). Socially responsible investing: sustainability indexes, ESG rating and information provider agencies. International Journal of Sustainable Economy, 2(4), 442-461. https://doi.org/10.1504/ijse.2010.035490

Escrig-Olmedo, E., Muñoz-Torres, M. J., Fernández-Izquierdo, M. Á., \& Rivera-Lirio, J. M. (2014). Lights and shadows on sustainability rating scoring. Review of Managerial Science, 8(4), 559-574. 10.1007/s11846-013-0118-0

Escrig-Olmedo, E., Fernández-Izquierdo, M. Á., Ferrero-Ferrero, I., Rivera-Lirio, J. M., \& Muñoz-Torres, M. J. (2019). Rating the raters: Evaluating how ESG rating agencies integrate sustainability principles. Sustainability, 11(3), 915. https://doi.org/10.3390/su11030915

Fernández Mateo, J. (2019). Los fundamentos epistemológicos de la transformación digital y sus efectos sobre la Agenda 2030 y los derechos humanos. Revista Icade. Revista de las Facultades de Derecho y Ciencias Económicas y Empresariales, (108). doi: https://doi.org/10.14422/icade.i108. y2019.004.

Fernández-Mateo, J \& Franco-Barrera, A. J. (2020) Animal Welfare for Corporate Sustainability: The Business Benchmark on Farm Animal Welfare. Journal of Sustainability Research, 2(3) https://doi.org/10.20900/jsr20200030

Fowler, S. J., \& Hope, C. (2007). A critical review of sustainable business indexes and their impact. Journal of Business Ethics, 76(3), 243-252. https://doi.org/10.1007/s10551-007-9590-2

Friede, G., Busch, T. \& Bassen, A. (2015) ESG and financial performance: aggregated evidence from more than 2000 empirical studies, Journal of Sustainable Finance \& Investment, 5:4, 210233, https://doi.org/10.1080/20430795.2015.1118917

Gladwin, T. N., Kennelly, J. J., \& Krause, T. S. (1995). Shifting paradigms for sustainable development: Implications for management theory and research. Academy of management Review, 20(4), 874-907. https://doi.org/10.5465/amr.1995.9512280024 
Graafland, J. J., Eijffinger, S. C., \& SmidJohan, H. (2004). Benchmarking of corporate social responsibility: Methodological problems and robustness. Journal of Business Ethics, 53(1-2), $137-$ 152. https://doi.org/10.1023/b:busi.0000039404.67854.e1

Hadani, M., Doh, J. P., \& Schneider, M. A. (2018). Corporate political activity and regulatory capture: how some companies blunt the knife of socially oriented investor activism. Journal of Management, 44(5), 2064-2093. https://doi.org/10.1177/0149206316638162

Harjoto, M. A. \& Jo, H. (2011). Corporate governance and CSR nexus. Journal of Business Ethics, 100, 45-67. https://doi.org/10.1007/s10551-011-0772-6

Huang, C. J. (2010). Corporate governance, corporate social responsibility and corporate performance. Journal of management \& organization, 16(5), 641-655.

https://doi.org/10.5172/jmo.2010.16.5.641

Jackson, G., \& Apostolakou, A. (2010). Corporate social responsibility in Western Europe: an institutional mirror or substitute? Journal of Business Ethics, 94(3), 371-394.

https://doi.org/10.1007/s10551-009-0269-8

Jamali, D., Safieddine, A. M., \& Rabbath, M. (2008). Corporate governance and corporate social responsibility synergies and interrelationships. Corporate Governance: An International Review, 16(5), 443-459. https://doi.org/10.1111/j.1467-8683.2008.00702.x

Jensen, K. B. (Ed.). (2013). A handbook of media and communication research: Qualitative and quantitative methodologies. London and New York. Routledge.

Jo, H. \& Harjoto, M. A. (2012). The causal effect of corporate governance on corporate social responsibility. Journal of business ethics, 106(1), 53-72. https://doi.org/10.1007/s10551-011-1052-1

Khan, M., Serafeim, G., \& Yoon, A. (2016). Corporate sustainability: First evidence on materiality. The accounting review, 91(6), 1697-1724. https://doi.org/10.2308/accr-51383

Kleine, A., \& Von Hauff, M. (2009). Sustainability-driven implementation of corporate social responsibility: Application of the integrative sustainability triangle. Journal of Business Ethics, 85(3), 517. https://doi.org/10.1007/s10551-009-0212-z

Kolk, A., \& Pinkse, J. (2010). The integration of corporate governance in corporate social responsibility disclosures. Corporate social responsibility and environmental management, 17(1), 15-26. https://doi.org/10.1002/csr.196

Likert, R. (1932). A technique for the measurement of attitudes. Archives of psychology, $\mathrm{n}^{\mathrm{o}} 140$.

Lo, S.F., \& Sheu, H.J. (2007). Is corporate sustain- ability a value-increasing strategy for business? Corporate Governance, 15, 345-358. https://doi.org/10.1111/j.1467-8683.2007.00565.x

López, M. V., Garcia, A., \& Rodriguez, L. (2007). Sustainable development and corporate performance: A study based on the Dow Jones sustainability index. Journal of Business Ethics, 75(3), 285-300.: https://doi.org/10.1007/s10551-006-9253-8

Mahoney, L. S., Thorne, L., Cecil, L., \& LaGore, W. (2013). A research note on standalone corporate social responsibility reports: Signaling or greenwashing?. Critical perspectives on Accounting, 24(4-5), 350-359. https://doi.org/10.1016/j.cpa.2012.09.008

Melé, D. (2009). Integrating personalism into virtue-based business ethics: The personalist and the common good principles. Journal of Business Ethics, 88(1), 227-244. https://doi.org/10.1007/ s10551-009-0108-y 
Money, K., \& Schepers, H. (2007). Are CSR and corporate governance converging? A view from boardroom directors and company secretaries in FTSE100 companies in the UK. Journal of General Management, 33(2), 1-11. https://doi.org/10.1177/030630700703300201

Montiel, I. (2008). Corporate social responsibility and corporate sustainability: Separate pasts, common futures. Organization \& Environment, 21(3), 245-269. https://doi. org/10.1177/1086026608321329

Montiel, I., Gallo, P. J., \& Antolin-Lopez, R. (2020). What on Earth should managers learn about corporate sustainability? A threshold concept approach. Journal of Business Ethics, 162(4), 857880. https://doi.org/10.1007/s10551-019-04361-y

Moreira, P. G. (Ed.). (2020). Revisiting Richard Rorty. Vernon Press.

OECD (2016). G20/OECD Principles of Corporate Governance: OECD Report to G20 Finance Ministers and Central Bank Governors. OECD Publishing. https://www.oecd.org/daf/ca/ Corporate-Governance-Principles-ENG.pdf

Parguel, B., Benoît-Moreau, F., \& Larceneux, F. (2011). How sustainability ratings might deter 'greenwashing': A closer look at ethical corporate communication. Journal of Business Ethics, 102(1), 15. https://doi.org/10.1007/s10551-011-0901-2

Ricart, J. E., Rodríguez, M. A., \& Sánchez, P. (2005). Sustainability in the boardroom: An empirical examination of Dow Jones Sustainability World Index leaders. Corporate Governance: the international journal of business in society, 5(3), 24-41. https://doi. org/10.1108/14720700510604670

Rodriguez-Fernández, M. (2016). Social responsibility and financial performance: The role of good corporate governance. Business Research Quarterly, 19(2), 137-151. https://doi. org/10.1016/j.brq.2015.08.001

Rossouw, G. J. (2012). Global business ethical perspectives on capitalism, finance and corporate responsibility: the impact of the global financial crisis of 2008. Asian Journal of Business Ethics, 1(1), 63-72. https://doi.org/10.1007/s13520-011-0006-0

Rorty, R. (2007). Philosophy as Cultural Politics: Volume 4. Philosophical Papers. Cambridge. Cambridge University Press.

Rubino, F., \& Napoli, F. (2020). What Impact Does Corporate Governance Have on Corporate Environmental Performances. An Empirical Study of Italian Listed Firms. Sustainability, 12(14), 5742. https://doi.org/10.3390/su12145742

Schäfer, H. (2005). International Corporate Social Responsibility Rating Systems. Journal of Corporate Citizenship, (20). https://doi.org/10.9774/GLEAF.4700.2005.wi.00012

Searcy, C., \& Elkhawas, D. (2012). Corporate sustainability ratings: an investigation into how corporations use the Dow Jones Sustainability Index. Journal of Cleaner Production, 35, 79-92. https://doi.org/10.1016/j.jclepro.2012.05.022

Shleifer, A., \& Vishny, R. W. (1997). A survey of corporate governance. The journal of finance, 52(2), 737-783. https://doi.org/10.1111/j.1540-6261.1997.tb04820.x

Shu, P. G., \& Chiang, S. J. (2020). The impact of corporate governance on corporate social performance: Cases from listed firms in Taiwan. Pacific-Basin Finance Journal, 101332. https:// doi.org/10.1016/j.pacfin.2020.101332 
Solomon, R. C. (1998). The moral psychology of business: Care and compassion in the corporation. Business Ethics Quarterly, 515-533.

Spitzeck, H. (2009). The development of governance structures for corporate responsibility. Corporate Governance: The international journal of business in society, 9(4), 495-505. https:// doi. org/10.1108/14720700910985034

Sun, M., Nagata, K., \& Onoda, H. (2011). The investigation of the current status of socially responsible investment indexes. Journal of Economics and International Finance, 3(13), 676.

Van Marrewijk, M. (2003). Concepts and definitions of CSR and corporate sustainability: Between agency and communion. Journal of Business Ethics, 44, 95-105. https://doi. org/10.1023/A:1023331212247

Vázquez, O. (2020). La RSC en las memorias anuales de las empresas del IBEX-35: análisis del ejercicio 2018. Observatorio de la Responsabilidad Social Corporativa. https://observatoriorsc. org/la-responsabilidad-social-corporativa-en-las-memorias-anuales-de-las-empresas-del-ibex-35/

Vitell, S. J. (2009). The role of religiosity in business and consumer ethics: A review of the literature. Journal of Business Ethics, 90(2), 155-167. https://doi.org/10.1007/s10551-010-0382-8

Wines, W. A. (2008). Seven pillars of business ethics: Toward a comprehensive framework. Journal of Business Ethics, 79(4), 483-499. https://doi.org/10.1007/s10551-007-9411-7

Windolph, S. E. (2011). Assessing corporate sustainability through ratings: challenges and their causes. Journal of Environmental sustainability, 1(1), 5. https://doi.org/10.14448/jes.01.0005 